\title{
Marketing Management: Realities and Requirements in the Context of Business Globalization and Internationalization of Companies
}

\author{
Liana MARCU \\ "Romanian-German" University of Sibiu, Sibiu, Romania \\ liana.marcu@roger-univ.ro \\ Diana Elena RANF \\ "Romanian-German" University of Sibiu, Sibiu, Romania \\ diana.ranfl@roger-univ.ro \\ Dănut Dumitru DUMITRAȘCU \\ "Lucian Blaga" University of Sibiu, Sibiu, Romania \\ dan.dumitrascu@ulbsibiu.ro
}

\begin{abstract}
Romanian organizations must open their doors to the outside, and for that managers must perceive and interpret all incoming signals to withstand competitive pressure to attract and retain customers, to be competent, to achieve maximum efficiency in their business processes.

The purpose of the selective scientific research aims the knowledge of certain issues within the organization, such as: current state of marketing management and customer orientation; specific business marketing management in conditions of business globalization and internationalization of companies; specific customer orientation;

Depending on the objectives pursued, the investigation carried out included two successive researches: an exploratory qualitative research and a descriptive quantitative research.

The general conclusion about the state of knowledge on marketing management in the context of business globalization and internationalization of companies is that the majority of respondents are aware of the importance of marketing management to support them when they face the daunting penetration option of global markets;

"Take Home Messages": The research has shown that the most important measure that organizations are considering in order to improve marketing management and make the organization's management efficient is to increase the place and role of marketing management in the overall management of the organization.
\end{abstract}

Keywords: global markets, client orientation, marketing management, internationalization 


\section{PURPOSE OF WORK}

We chose this primary objective in the construction of our work to identify the extent to which, at present, both the literature and practice of marketing management is prepared to implement and manage a new type of marketing management. The analysis of the extent to which the concepts that this management subsystem operates with are known, is the starting point of any scientific attempt.

Double focusing the company's efforts on superior products and services - therefore on quality and total services - as a source of consumer satisfaction and as a means of establishing lasting relationships with them, signifies, according to $\mathrm{Ph}$. Kotler - the essence of specific approach of marketing management. To be successfully used, marketing must be fully integrated into the organizational structures of the third millennium entities. Trends in the development of marketing management process identified and addressed in conjunction with the manner in which they currently operate and depending on marketing environmental factors influencing the organization.

Obtaining competitive advantages is foreshadowed to be increasingly difficult. Former competitive concepts that were once successful, such as product differentiation, technological supremacy or lower costs are no longer sufficient in the current market conditions, to ensure long-term profitable, economically advantageous position of the company.

More and more organizations are in a position to offer products for specific target groups at the required quality and at competitive prices. Thus, taking into account their objective quality, they have become interchangeable to the customer. Because of this it was necessary to seek new sources of differentiation, that would be appreciated by the client and allow the organization to maintain a harder edge to match by the competition, for a longer period of time.

Both specialty literature and practice consider customer satisfaction a central indicator in assessing an organization in providing quality services. Customer satisfaction shows to what extent the offerer's promises and achievements overlap with customer expectations. We can say that an organization that has only satisfied customers is a customer-oriented enterprise.

For these reasons and others, we considered it absolutely necessary to believe customer orientation and its role in marketing management as a major research objective, both documentary and applied to our paper.

The starting point of the study conducted was the consultation of literature in the field (Anon, A.\& Perry, C. 2002, Bogdan, I. 2007, Buttle, F. 2004, Charlesworth A., Gay R. Esen R. 2009, Dumitru, I. 2004). 


\section{METHODOLOGY OF RESEARCH}

Depending on the objectives, the investigation carried out included two successive researches: an exploratory qualitative research and a descriptive quantitative research.

Identifying the problem and purpose is one of the most important phases of a research. The purpose of the selective scientific research is closely related to the problems and issues raised in substantiating the study. Thus, it aims to highlight, describe the characteristics of marketing management and customer orientation at universities, $\mathrm{PhD}$ students and researchers, managers and customers of companies in Sibiu county and to determine the extent of the differences in terms of needs, attitudes or opinions between the different categories of respondents, between theory and practice, between what should be done and what is being done.

To operationalize the research the following objectives and hypotheses have been established:

\section{Table 1: Objectives and hypotheses of the research}

\begin{tabular}{|c|c|c|}
\hline & $\begin{array}{c}\text { OBJECTIVES OF THE } \\
\text { RESEARCH }\end{array}$ & HYPOTHESES \\
\hline$Q 1$ & $\begin{array}{l}\text { Analysis of the current state of } \\
\text { knowledge on marketing } \\
\text { management: realities and } \\
\text { requirements in the context of } \\
\text { business globalization and } \\
\text { internationalization of companies }\end{array}$ & $\begin{array}{l}\boldsymbol{H}_{1^{-}} \text {Marketing management is largely } \\
\text { influenced by change, business globalization } \\
\text { and internationalization of companies } \\
\boldsymbol{H}_{2}-\text { Most respondents consider that } \\
\text { marketing management can adapt to } \\
\text { contemporary world's changes }\end{array}$ \\
\hline$Q 2$ & $\begin{array}{l}\text { Determination of the degree in } \\
\text { which customer orientation is } \\
\text { considered an essential component } \\
\text { of marketing management }\end{array}$ & $\begin{array}{l}\text { H3 - The majority of respondents believes } \\
\text { that customer orientation is crucial to the } \\
\text { success of organizations. } \\
\boldsymbol{H}_{4}-\text { Most respondents believe that the } \\
\text { organization successfully applies methods and } \\
\text { techniques of customer orientation. }\end{array}$ \\
\hline
\end{tabular}

The research was conducted through four questionnaires with a relatively high degree of structuring, distributed directly to the four categories of respondents (academics, $\mathrm{PhD}$ students/researchers, managers, clients). These questionnaires are structured relatively the same, with the top five common questions and the last, and the rest covering the same goals, but adapted to the typology of the respondent.

Therefore, dichotomous and multiple choice closed questions and were used, open questions, mixed questions. 
To measure the variables under the study (baseline variables, descriptive variables, organizational variables, situational variables) the most suitable type of scaling and the scaling method should be used. As a method of scaling, the Likert scale was used.

The selective scientific research carried out for a confidence level of $95 \%$ and a margin of error of $10 \%$, the sample will be of:

$$
n=\frac{1,96 \times 0,5 \times(1-0,5)}{0,1^{2}}=96
$$

Therefore, the minimum number of duly completed questionnaires, which should be collected and processed, is 96. Maintaining the confidence level of 95\%, and given that a number of 200 questionnaires was collected and validated, we determined the maximum margin of error $\left(\Delta_{\omega \max }\right)$ :

$$
\Delta_{\omega_{\max }}=t \sqrt{\frac{p \times(1-p)}{n}}=1,96 \sqrt{\frac{0,50(1-0,50)}{110}}=9,4 \%
$$

From the category of organizational restrictions that have arisen in determining the sample size, we mention: the financial availability of the researcher (actually, it was the most important, all expenses being borne by the researcher), the time given to the research, the lack of reliable operators etc.

We believe that the most important limitation of the research carried out is due to the sample size (200 respondents) and fairly high margin of error (10\%) for a confidence level of 95 .

\section{RESULTS OF THE RESEARCH AND TAKE HOME MESSAGES}

In order to operationalize the research a series of questions were formulated common to all categories of respondents, in order to achieve a series of comparative studies in the research. These comparative studies have allowed us to get extra information and motivation regarding the interdependence of the various aspects of marketing management and the training and the background of respondents. (Marcu, 2011)

The first question addressed to all categories of respondents concerns the fundamental concepts with impact on marketing management: change, business globalization and internationalization of companies. The data obtained in question v1 are shown in table 2 and graphically described in figure 1 :

Table 2: State of knowledge of marketing management in the context of change, business globalization and internationalization of companies

\begin{tabular}{|c|c|c|c|c|}
\hline & & Frequency & Percentage & $\begin{array}{c}\text { Valid } \\
\text { percentage }\end{array}$ \\
\hline Valid & 200 & & & \\
\hline & Unimportant & 8 & 4 & 4 \\
\hline & Less important & 16 & 8 & 8 \\
\hline & Neutral & 33 & 16,5 & 16,5 \\
\hline & Important & 41 & 20,5 & 20,5 \\
\hline
\end{tabular}




\begin{tabular}{|c|c|c|c|c|}
\hline & Very important & 102 & 51 & 51 \\
\hline Total & & 200 & 100 & 100 \\
\hline Mean & $\mathbf{4 . 0 6}$ & & & \\
\hline
\end{tabular}

Processing responses leads us to conclude that most respondents (51\%) attached great importance to the concepts of change, business globalization and internationalization of companies and to the impact that these concepts have in marketing management. This result leads us to note the awareness of the respondents of the need to know and operationalize these concepts in organizations' management, and especially in marketing management. A neutral opinion on these concepts have $16,5 \%$ of respondents, $8 \%$ of respondents gave little importance, while only 2 respondents representing $4 \%$ consider the concepts of change, business globalization and internationalization of companies in the current economic context unimportant.

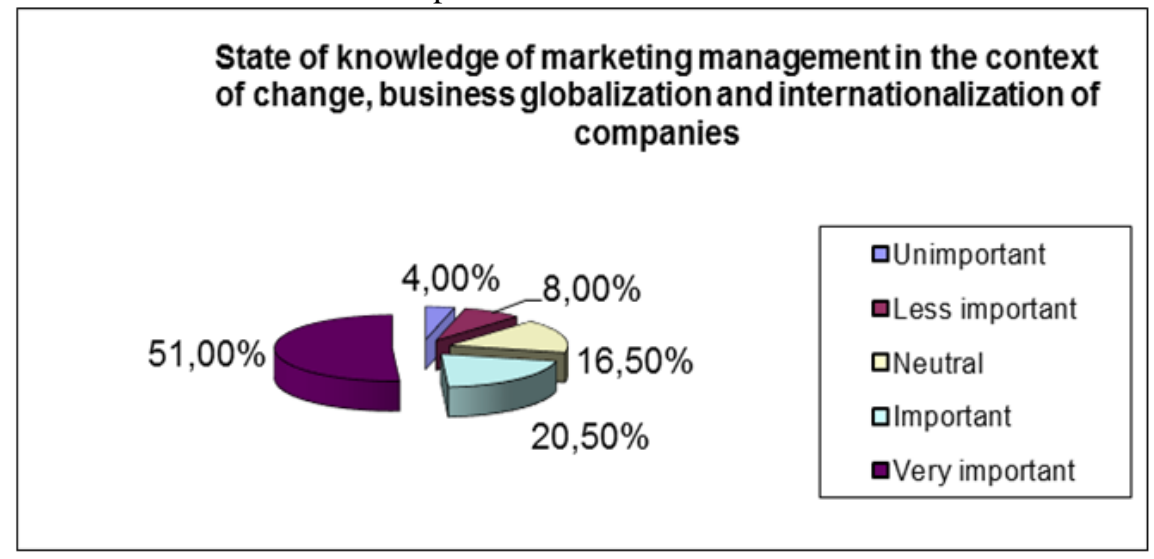

\section{Figure 1: State of knowledge of marketing management in the context of change, business globalization and internationalization of companies}

The average of responses (5- very important, 4- important, 3- neutral, 2- little important, 1unimportant) is of 4,06 and are within the "important" area, so that the hypothesis launched before the research (H1-Marketing management is largely influenced by change, business globalization and internationalization of companies) is confirmed.

The formulated question was mixed and therefore measures to adapt the marketing management to the listed changes were formulated. Among those listed by respondents include: the identification of new markets and consumer segments, better training for managers in marketing management, finding new sources of competitive advantage in international markets, reconfiguring and rethinking organizational objectives, thorough research of global environmental conditions, increasing structural and dimensional flexibility.

In conclusion, given that $84 \%$ of respondents listed at least one solution to adapt the marketing management to business globalization and internationalization of companies, we 
can say that our hypothesis (H2 - Most respondents find that marketing management can adapt to contemporary world's changes) is confirmed.

For details, v1 question pairing with the category of respondents was carried out (State of knowledge of marketing management in the context of change, business globalization and internationalization of companies/category of respondent), the information obtained being presented in table 3 and graphically described in figure 2 .

Table 3: State of knowledge of marketing management in the context of change, business globalization and internationalization of companies depending on the category of respondents

\begin{tabular}{|c|c|c|c|c|c|}
\hline & \multicolumn{4}{|c|}{ Category of respondents } & \multirow{2}{*}{ Total } \\
\cline { 2 - 6 } & Academics & $\begin{array}{c}\text { PhD } \\
\text { students/researchers }\end{array}$ & Managers & Clients & \\
\hline \multirow{2}{*}{$\begin{array}{c}\text { Unimportant } \\
\%\end{array}$} & - & - & 2 & 6 & 8 \\
\cline { 2 - 6 } & - & - & $4 \%$ & $12 \%$ & $4 \%$ \\
\hline $\begin{array}{c}\text { Less } \\
\text { important } \\
\%\end{array}$ & 1 & 1 & 4 & 10 & 16 \\
\cline { 2 - 6 } & $2 \%$ & $2 \%$ & $8 \%$ & $20 \%$ & $8 \%$ \\
\hline $\begin{array}{c}\text { Neutral } \\
\%\end{array}$ & 4 & 7 & 9 & 13 & 33 \\
\cline { 2 - 6 } & $8 \%$ & $14 \%$ & 4 & $26 \%$ & $16,5 \%$ \\
\hline $\begin{array}{c}\text { Important } \\
\%\end{array}$ & 18 & $32 \%$ & $8 \%$ & $6 \%$ & $20,5 \%$ \\
\hline $\begin{array}{c}\text { Very } \\
\text { important } \\
\%\end{array}$ & 27 & 26 & $62 \%$ & $36 \%$ & $51 \%$ \\
\cline { 2 - 6 } & $54 \%$ & $52 \%$ & 50 & 50 & 200 \\
\hline $\begin{array}{c}\text { Total } \\
\%\end{array}$ & 50 & $100 \%$ & $100 \%$ & $100 \%$ & $100 \%$ \\
\cline { 2 - 6 } & $100 \%$ & & & 18 & 102 \\
\hline
\end{tabular}

It thus appears from the information provided that the two categories engaged in practical activity, namely managers (4\%) and customers (12\%) are those with answers which consider unimportant the concepts of change, business globalization and internationalization of companies, especially in marketing management. Customers are the ones who feel in the greatest proportion (20\%) of these concepts as being less important, while a neutral view is found in all categories of respondents, the highest percentage is thus again found at the customers. 


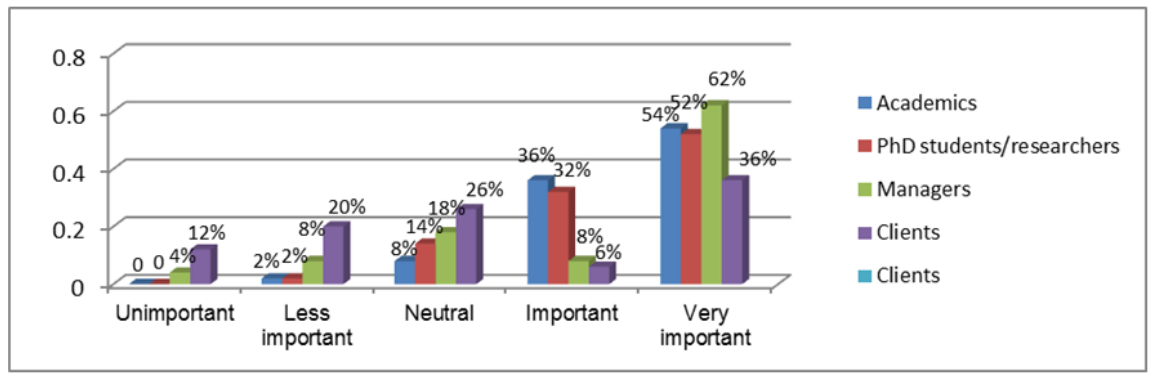

Figure 2. State of knowledge of marketing management in the context of change, business globalization and internationalization of companies depending on the category of respondents

Academics and $\mathrm{PhD}$ students considered in significant percentages (36\% and 32\% respectively) these concepts as important, and they also consider them as very important in a proportion of $54 \%$ and $52 \%$. What is noteworthy, however, is the highest percentage of the category that considers as very important these concepts is that of managers and the lowest percentage, of customers. This shows the diametrically opposed views of the two categories directly involved in practical activity.

In order to achieve the second objective the v2 question was formulated, seeking to determine whether customer orientation is considered an essential component of marketing management. The information obtained after processing the data are shown in table 4 and graphically described in figure 3 .

Table 4: The degree to which customer orientation is considered an essential component of marketing management

\begin{tabular}{|c|c|c|c|c|}
\hline & & Frequency & Percentage & $\begin{array}{c}\text { Valid } \\
\text { percentage }\end{array}$ \\
\hline Valid & 200 & & & \\
\hline & Unimportant & 3 & $1 \%$ & $1 \%$ \\
\hline & Less important & 7 & $3 \%$ & $3 \%$ \\
\hline & Neutral & 12 & $6 \%$ & $6 \%$ \\
\hline & Important & 47 & $24 \%$ & $24 \%$ \\
\hline & Very important & 131 & $66 \%$ & $66 \%$ \\
\hline Total & & 200 & 100 & 100 \\
\hline Media & $\mathbf{4 . 4 8}$ & & & \\
\hline
\end{tabular}




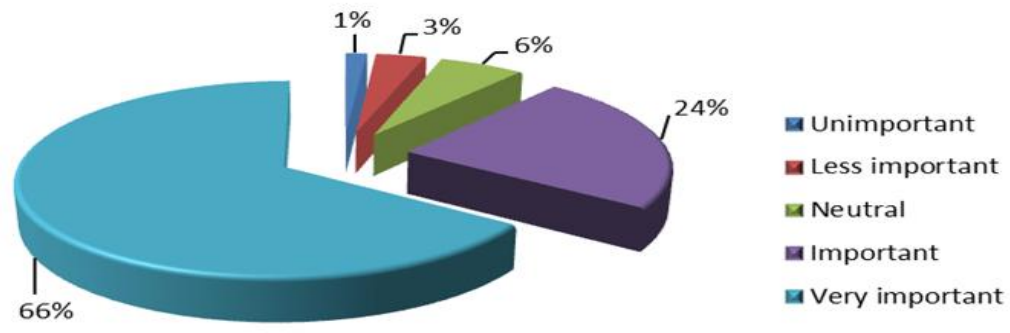

\section{Figure 3. Degree to which customer orientation is considered an essential component of marketing management}

From the above information we could conclude that most respondents $(65,5 \%)$ believe that customer orientation is a strong component in marketing management while 23,50\% consider it important. $6 \%$ of respondents show a neutral opinion while $3,5 \%$ consider it less important. Only 3 respondents $(1,5 \%)$ consider this concept as totally unimportant. The score of responses is 4,48 (on the scale 5-very important, 4- important, 3- neutral, 2least, 1- unimportant) and in conclusion, the hypothesis (H3- The majority of respondents believes that customer orientation is crucial to the success of organizations) is confirmed, which leads us to conclude that the majority of respondents are aware that the organization's activities should be conditional on the customer's requirements.

From the replies we could not identify specific methods and techniques of customer orientation listed by the respondents, and thus we can say that $\mathrm{H} 4$ (H4 - Most respondents believe that the organization successfully applies methods and techniques of customer orientation) is invalidated.

\section{FINAL CONCLUSION}

Our scientific approach, along with its special place that it holds within the modern organizations in the frame of business globalization and companies internationalization, can be considered as of a certain complexity and difficulty that must be evaluated, handled and approaches with a certain amount of attention.

One of the conclusions of the research refers to the concept of change, although widely accepted and debated in the academic environment, still very less accepted by managers and clients.

Of the four hypotheses, the fourth is invalid, resulting that the respondent organizations did not apply successful methods and techniques of customer orientation. 
From the answers given by respondents to our request to advance solutions for the marketing management to get closer to customers, the most significant are:

- the intensification of marketing research;

- the formation of interdisciplinary teams to analyse the needs and demands of customers;

- $\quad$ using previous experience for assortment diversification, transfer of knowledge and know-how;

- networking and outsourcing of certain services, use of experts, external benchmarking.

\section{REFERENCES}

Anon, A.\& Perry, C. (2002) A Customer Oriented New Service Development Process. Journal of services marketing, 16(6);

Bogdan, I. (2007). Managementul afacerilor internaţionale, Sibiu, Editura ULBS;

Buttle, F. (2004). Customer relationship management: Concepts and tools, Volume 13, Butterworth-Heinemann;

Charlesworth A., Gay R., Esen R. (2009) Marketing on-line. O abordare orientata spre client., Bucuresti, Ed All;

Dumitru, I. (2004). Marketing strategic. O abordare din perspectiva globalizării, Bucureşti, Editura Uranus;

Marcu (Brezai) L. (2011) Managementul marketingului în contextul schimbării,

globalizării afacerilor şi internaţionalizării firmelor, Unpublished doctoral Thesis, ULBS SIBIU. 